\title{
KVANTIFIKÁCIA RIZíK
}

\author{
RISKS QUANTIFICATION
}

Riziko je sprievodným javom každej ludskej činnosti, každej spoločenskej existencie, každého bytia. Riziko nevzniká náhodne, ale je súčastou neistoty a neurčitosti, s ktorou každá bytostná existencia je spojená. Každý sám posúdi, aký vplyv má riziko na jeho vlastné konanie a aká je v danej chvíli jeho významnost'. Pravda, človek žije $v$ istom spoločenskom i prírodnom prostredí, ktoré tiež obsahujú rizikové prvky. Preto je účelné stanovit isté pravidlá, ako možno riziká ocenit.' V tomto príspevku sa popisujú niektoré z možných riešení.

\section{Podmienky pre kvantifikáciu rizík}

Človek svoje konanie nemôže vykonávat iba v prostredí istoty, pretože istota sa môže dosiahnut iba za predpokladu, že výsledok ludskej činnosti je jednoznačný, že nejestvuje nijaké iné alternatívne riešenie, pre ktoré by sa musel človek rozhodovat. Ak človek koná, koná vždy pod vplyvom istých okolností. Pochopitelne usiluje $\mathrm{o}$ to, aby jeho konanie malo nielen zmysel, ale aby viedlo $\mathrm{k}$ očakávanému výsledku a to čo možno bez najmenších prekážok. Svoje úsilie o výsledok vedome či podvedome podriaduje istým zásadám pričinnosti, kauzality s tým úmyslom, aby sa vyhol prípadným čiastkovým neúspechom a dosiahol svoj ciel racionálnym spôsobom. Cielové konanie nie je však vždy priamočiare, je spojené s prekážkami, neznalostami o budúcnosti, alebo i nedostatočným ovládaním či prispôsobením sa prostrediu, $v$ ktorom človek svoje aktivity vykonáva.

Riziko súvisí tak s objektívnou realitou ako aj so subjektívnym konaním. Človek žije v istom životnom prostredí, ktoré je dané prírodnými i spoločenskými podmienkami. Pravda, tieto podmienky môže človek istým spôsobom ovplyvňovat, ale jeho bezprostredný vplyv na prostredie je vel'mi obmedzený. Človek si nemôže vytvorit vlastný svet, ktorý by zodpovedal jeho ideálom, ale musí sa podriadit podmienkam, $\mathrm{v}$ ktorých žije a pôsobí. Na druhej strane však človek je z existenčných dôvodov povinný konat v danom prostredí. Ked'že prostredie neovláda, koná $\mathrm{v}$ ňom $\mathrm{s}$ istou mierou neurčitosti, neistoty a nepozná dopredu, aký výsledok jeho aktivity dosiahnu. Takáto neurčitost je zdrojom rizika $\mathrm{z}$ dosiahnutelného výsledku.

Ludské konanie sa viaže vždy na konkrétnu činnost' a konkrétne prostredie. Jeho činnost̉ je vždy spojená s istou mierou rizika.
Risk is an inherent phenomenon of every human activity, of every social existence, of every human being. Risk is not coming into existence accidentally but is a part of incertitude and uncertainty that each entity is coupled with. Everybody shall judge what kind of influence has an occurring risk on his own action and what is its significance in a given while. In fact, human being lives in certain social and natural environment which also contains danger fragments. Therefore, it advisable to determine some rules how to evaluate possible risk situations. In this article some of possible solutions are interpreted.

\section{Prerequisites for risks quantification}

Man cannot perform his own activity only in the environment of certainty since a certainty can be reached only under such assumption that a result of human activity is unique and that any other positive alternative solution does not exist. When man acts, he acts always under influence of certain circumstances. Naturally, man endeavours to act in such a way that his actions have not only significance but also lead without whatever possible obstacles to an expected result. Man wittingly or unconsciously subordinates his effort to reach an outcome under condition of causality in order to evade a possible partial rebuff and to reach the aim in a rational way. The aiming result is not always reached straightforwardly. To reach a required result is always connected with obstacles, with non-acquaintance of the future, or even with insufficient command or with insufficient adaptability to the real environment in which man executes his own activities.

The risk relates to objective reality as well as to subjective activity. Man is living in the specific living environment that is given by natural and social conditions. Man can in some way influence these conditions but his direct impact on the environment is very limited. Man cannot create his own world that would respond to his ideals but he has to subordinate himself to the conditions he lives with. On the other hand, man needs to act in the given environment due to the reasons of existence. Since man does not manage the environment he acts in it with some rate of uncertainty, incertitude and does not know in advance what kind of result his activities can achieve. This kind of uncertainty is a source of risk from accessibility of the result.

\footnotetext{
* Prof. Jan Mikolaj, DrSc.

Faculty of Special Engineering, University of Žilina, 1. mája 32, 01026 Žilina, Slovakia
} 
Riziko ako miera neurčitosti sa teda viaže vždy na určité konanie a na určité prostredie, $v$ ktorom tvorivá činnosṫ človeka prebieha. Miera rizika súvisiaca s konkrétnym konaním môže byt vel'mi rozmanitá. Závisí to od toho, ako človek svoju prácu ovláda a ako sa prostredie k práci človeka zachová. Preto riziko nemá objektívnu platnost', ale viaže sa vždy na špecifickú činnost’ a špecifické prostredie. Mierou rizika potom bude miera neistoty a neurčitosti s akou človek svoje špecifické činnosti vykonáva.

Určitost v konaní sa môže charakterizovat ako stav, v ktorom sa dosiahne jednoznačný výsledok. V praktickom konaní sa takéto výsledky dajú dosahovat prevážne vtedy, ked' sa deje vykonávajú na základe skúseností, empírie. V technologických procesoch sa vyskytujú vel'mi často v procesoch bez možnosti výberu a takmer výhradne $\mathrm{v}$ synchronizovaných a automaticky riadených procesoch.

Neurčitost možno chápat tak, že výsledok bude síce dosiahnutý $\mathrm{s}$ istou pravdepodobnostou, ale mieru takejto pravdepodobnosti nemožno bezpečne stanovit?

Riziko bude taký stav neurčitosti, pri ktorom mieru pravdepodobnosti možno odhadnút. Pri alternatívnych riešeniach možno $\mathrm{s}$ istotou tvrdit, že jedno $\mathrm{z}$ riešení sa vyskytne, pričom pravdepodobnost jeho výskytu sa dá očakávat alebo odhadnút

Uvedené ponímania môžu byt východiskom pre stanovenie miery neurčitosti a miery rizík. Stanovenie takejto miery chápeme ako rozsah, kvantifikáciu rizika. Každé riziko skôr, ako sa stanovi jeho rozsah, musí sa identifikovat', musí sa stanovit jeho obsah. Stanovenie obsahu rizika je vecou príslušnej vednej disciplíny, $\mathrm{v}$ rámci ktorej sa riziká analyzujú.

Kvantifikáciou rizík sa zaoberá samostatná disciplína, riziková analýza. Riziko býva predmetom aj iných druhov analýz. Z nich treba predovšetkým spomenút analýzy spolahlivosti, ktoré sa uplatňujú pri skúmaní technických a technologických zariadení, analýzy rozhodovania, ktoré sa zasa uplatñujú v riadiacich procesoch, analýzy akosti (kvality), ktoré sa uplatňujú v produkčných procesoch atd’. Ich súčastou býva vždy analýza rizík. Vzhladom na rozsah príspevku nebudeme sa týmito druhmi analýz zaoberat.

Pri rizikovej analýze sa vychádza z viacero koncepcií. Najviac používanými sú tieto $\mathrm{z}$ nich:

- koncepcia pravdepodobnosti výskytu rizika,

- koncepcia štandardných rozdelení,

- koncepcia teórie úžitku,

- koncepcia vplyvu rizika na hodnotu firmy.

V tomto príspevku sa sústredíme na tie riešenia, ktoré súvisia s hospodárskymi otázkami predovšetkým preto, lebo výsledky aktívnej produktívnej činnosti človeka sa hodnotia hlavne ich hodnotovými kategóriami.
Human doing is always connected with particular activity and specific environment. The human activity is also always connected with some rate of risk. The risk as a measure of uncertainty is always related to specific procedure and to specific environment in which the creative activiity of man runs over. The rate of the risk related to specific activity can be very miscellaneous. It depends on man how he commands his work and what attitude the environment retains to his activities. Therefore the risk does not have unprejudicated validity but binds itself to special activity and specific environment. The measure of the risk shall be then a measure of uncertainty with which man executes his individual activity.

Certainty in human doing can be characterised as a state where only one outcome can be found. In practical life such outcomes can be achieved mostly when actions are performed on a basis of past experience. In technological operations certainty occurs very often in processes where device does not have any choice and almost exclusively in synchronised and automatically controlled processes.

Uncertainty can be apprehended in such a case where the outcome can be achieved only with certain probability but a measure of such probability cannot be safely determined.

Risk is such a state of uncertainty where the measure of probability can be assessed. In alternative solutions it can be claimed with certainty that one of alternative outcomes occurs and the probability of its occurrence can be expected or assessed.

Indicated understandings can be used as a starting point for determination of uncertainty and risk measure. The determination of risk measure can be considered as a size of its quantification. Each risk before its size is determined must be identified according to its sense. Risk estimation is a matter of relevant discipline within the frame of which the risk is analysed.

Risk analysis is an independent discipline that deals with the risk quantification. Risk is an object of other kinds of analyses, too. The analyses of reliability that are applied in the testing of technical and technological equipment, decision-making analyses used in managerial processes, quality analyses used in productive processes can be mentioned. The risk analysis must always be a part of the mentioned analyses. With regard to the size of this article we are not going to pay attention to these kinds of analyses and to appropriate risk.

In practical and theoretical life several conceptions can be found for risk analysis. Among them we will pay attention to the following:

- conception of risk probability occurrence,

- conception of standard distributions,

- conception of utility theory,

- conception of risk influence on firm value.

We can concentrate our attention to those solutions that relate to economic problems. We will do that mainly because the results of productive activity of human being are evaluated especially by value categories. 


\section{Koncepcia pravdepodobnosti výskytu rizika}

Koncepcia pravdepodobnosti výskytu rizika sa opiera o poznatky z teórie pravdepodobností. Pravdepodobnost', že sa jav vyskytne, predstavuje príležitost', možnost', alebo výhodu tohto javu voči javu, ktorý sa nevyskytne. To sa vztahuje aj na riziko. Aj riziko sa môže vyskytovat' $\mathrm{s}$ istým pravdepodobnostným rozdelením a to závisle, alebo nezávisle od daného funkčnosti javu. $\mathrm{V}$ tom druhom prípade je riziko závislé od prostredia, $\mathrm{v}$ ktorom jav prebieha.

Podkladové vyčíslenie rozdelenia pravdepodobnosti výskytu sa zostavuje v maticiach výstupov (efektov), v ktorých sa javom priradujú jednotlivé hodnoty v súvislosti s obsahom javu, výskytu javu a jeho úžitku (výnosovosti, efektu). Takéto matice sa nazývajú výnosovými maticami (angl.: payoff matrix) a slúžia ako numerický základ pre vyčíslenie ocenení pri analýze tzv. očakávanej hodnoty.

Riešenie môžeme dokumentovat jednoduchým príkladom. Zostrojme maticu, $\mathrm{v}$ ktorej $\mathrm{v}$ riadkoch sa vyjadria stavy vybratých javov $\left(S_{1-m}\right)$ a v stípcoch z príslušného stavu plynúci „výnos“ $\left(V_{1-n}\right)$. Hodnoty $P_{i j}$ predstavujú pravdepodobnosṫ získaného výnosu $j$ viažuceho sa na skúmaný jav $i$, teda $P\left(V_{j} / S_{i}\right)$. Stanovenie miery pravdepodobnosti je vecou empírie, ale súčasne i rizika.

Matica bude mat takýto tvar:

$$
\begin{array}{llllll} 
& V_{1} & \ldots & V_{i} & \ldots & V_{n} \\
& & & & & \\
S_{1} & P_{11} & \ldots & P_{1 j} & \ldots & P_{1 n} \\
\vdots & & & & & \\
S_{i} & \ldots & \ldots & P_{i j} & \ldots & \ldots \\
\vdots & & & & & \\
S_{m} & P_{m 1} & \ldots & P_{m j} & \ldots & P_{m n}
\end{array}
$$

Stav istoty by nastal v takom prípade, keby všetky $P_{i j}$ získali hodnoty 1 alebo 0 .

Predpokladajme, že pravdepodobnost’ výskytu javu pri jeho relevantnom výnose je daná týmito hodnotami:

$$
\begin{aligned}
& P\left(S_{1} / V_{1}\right)=0.8 \quad P\left(S_{1} / V_{2}\right)=0,2 \\
& P\left(S_{2} / V_{1}\right)=0.7 \quad P\left(S_{2} / V_{2}\right)=0,3
\end{aligned}
$$

Predpokladajme dalej, že vel'kost’ peňažných hodnôt jednotlivých výnosov pozorovaných javov je takáto:

$$
\begin{array}{ll}
\left(S_{1} / V_{1}\right)=20 & \left(S_{1} / V_{2}\right)=60 \\
\left(S_{2} / V_{1}\right)=30 & \left(S_{2} / V_{2}\right)=40
\end{array}
$$

$\mathrm{Z}$ danej pravdepodobnosti a hodnoty ich peňažného vyjadrenia vypočíajme hodnotu tzv. očakávanej hodnoty $(E V)$ :

$$
\begin{aligned}
& E V\left(S_{1}\right)=(0.8)(20)+(0.2)(60)=28 \\
& E V\left(S_{2}\right)=(0.7)(30)+(0.3)(40)=33
\end{aligned}
$$

\section{Conception of risk probability occurrence}

The conception of risk probability occurrence is based on the theory of probability. Probability that a phenomenon occurs presents an opportunity, a possibility, or an advantage of this phenomenon towards a phenomenon, which does not occur. That attitude basically relates to the risk, too. The risk can also occur with some probability distribution dependently or independently on given phenomenon function. In the second case the risk is dependent on the environment in which the phenomenon occurs.

The basic enumeration of probability occurrence is assembled in outputs (effects) matrix in which are assigned single phenomena values in relation to phenomenon contents, phenomenon occurrence and phenomenon utility (income, effect). Such matrices are called payoff matrices and serve as a numerical basis for evaluation of expected values.

A solution can be indicated by a simple example. Let us construct a matrix. In lines is expressed the state of chosen phenomenon $\left(S_{1-m}\right)$ and in columns "a payoff " that flows from the relevant phenomenon state $\left(V_{1-n}\right)$. The values $P_{i j}$ present a probability of the obtained pay-off $j$ that is related to the investigated phenomenon $i$, in other words $P\left(V_{j} / S_{i}\right)$. The estimation of probability measure is a matter of empiricism and at the same time it is an estimation of the risk.

The matrix will have the following configuration:

$$
\begin{array}{llllll} 
& V_{1} & \ldots & V_{i} & \ldots & V_{n} \\
& & & & & \\
S_{1} & P_{11} & \ldots & P_{1 j} & \ldots & P_{1 n} \\
\vdots & & & & & \\
S_{i} & \ldots & \ldots & P_{i j} & \ldots & \ldots \\
\vdots & & & & & \\
S_{m} & P_{m 1} & \ldots & P_{m j} & \ldots & P_{m n}
\end{array}
$$

The state of certainty would occur in case if all $P_{i j}$ obtained the values 1 (one) or 0 (zero).

Let us expect that the phenomenon probability occurrence with a corresponding income will be given by the following values:

$$
\begin{array}{ll}
P\left(S_{1} / V_{1}\right)=0.8 & P\left(S_{1} / V_{2}\right)=0,2 \\
P\left(S_{2} / V_{1}\right)=0.7 & P\left(S_{2} / V_{2}\right)=0,3
\end{array}
$$

Let us further assume that the amounts of financial values of a single income at the observed phenomena are:

$$
\begin{array}{ll}
\left(S_{1} / V_{1}\right)=20 & \left(S_{1} / V_{2}\right)=60 \\
\left(S_{2} / V_{1}\right)=30 & \left(S_{2} / V_{2}\right)=40
\end{array}
$$

From the given probability and from their financial values the so-called expected value $(E V)$ can be calculated:

$$
\begin{aligned}
& E V\left(S_{1}\right)=(0.8)(20)+(0.2)(60)=28 \\
& E V\left(S_{2}\right)=(0.7)(30)+(0.3)(40)=33
\end{aligned}
$$


Očakávaná hodnota je vyššia pre jav $S_{2}$ ako pre jav $S_{1}$. Riziko výberu bude nižšie, ak sa vyberie variant $S_{2}$.

Koncepcia pravdepodobnosti výskytu rizika nachádza svoje reálne vyjadrenie aj v tzv. očakávanej hodnote. Očakávanou hodnotou sa rozumie ideálna hodnota, ktorá vznikne z výsledku pravdepodobného rozdelenia výnosov všetkých sledovaných javov.

Očakávaná hodnota $(E V)$ sa definuje vztahom:

$$
E V(\pi)=\sum_{i=1}^{n}\left(\pi_{i} p_{i}\right)
$$

kde: $E V$ je očakávaná hodnota vyjadrená váženým priemerom rôznych možných výstupov, z ktorých každý je vážený pravdepodobnostou svojho výskytu, $\pi_{i}$ - výnosovost i-tého výstupu, $p_{i}-$ pravdepodobnost výskytu i-tého výstupu.

Odchýlka $\left(r_{i}\right)$ každého možného výstupu od očakávanej hodnoty sa vyjadrí vztahom:

$$
r_{i}=\pi_{i}-E V(\pi)
$$

a je východiskom pre výpočet rozptylu $\left(\sigma^{2}\right)$, ktorý je mocninou odchýlky.

$$
\begin{aligned}
& \text { Štandardná odchýlka }(\sigma) \text { je odmocninou rozptylu: } \\
& \sigma=\sqrt{\sum_{i=1}^{n}\left[\pi_{i}-E V(\pi)\right]^{2} p_{i}}
\end{aligned}
$$

a využiva sa tiež pri meraní rizika. Čím menšia je štandardná odchýlka, tým menšie je riziko vyplývajúce zo skúmaného javu.

Vel'kosti rizika sa chápe ako absolútna hodnota rizika. Relatívna hodnota rizika predstavuje rozptyl možných návratností výnosov (efektov) v porovnaní s očakávanými pravdepodobnými výnosmi vyjadrenými vo výnosovej matici. Na vyjadrenie relatívneho rizika sa použiva koeficient variácie $v$. Pri využití koncepcie pravdepodobností sa koeficient variácie vyjadrí vztahom: $v=\sigma / E V(\pi)$.

Uvedené štatistické vyjadrenia sa použivajú pri posudzovani alternatív predkladaných projektov a ich úžitkovosti. Štandardná odchýlka a koeficient rozptylu sú založené na komplexnom posudzovaní návratnosti vložených prostriedkov. Riziko sa posudzuje podla celkovej úžitkovosti jednotlivých alternatív i podla jednotlivých zložiek, ktoré sa na celkovom výsledku podielajú.

Vo finančníctve sa vytvorila samostatná koncepcia merania čiastkových rizík súvisiacich s jednotlivými vkladmi v podnikovom portfóliu. Táto koncepcia sa nazýva koncepciou beta $(\beta)$ a vyjadruje mieru systematickej variabilnosti alebo kovariancie (spolusúčinnosti) návratnosti každej jednej časti aktív z celkových aktív. Koeficient $\beta$ sa vyjadruje vztahom:

$$
\beta_{i I}=\frac{\sigma_{i I}}{\sigma_{I}^{2}}, \quad(i \in I),
$$

kde I predstavuje tzv. trhový index, ktorým sa vyjadruje podiel jednotlivých druhov aktív na trhu týchto aktív.
The expected value has a higher value for the phenomenon $S_{2}$ than for the phenomenon $S_{1}$. The risk selection will decrease when the alternative $S_{2}$ is chosen.

The conception of risk probability occurrence finds its objective expression in the expected value, too. By the expected value we can understand an ideal value that arises from the results of probability distribution of incomes coming from all observed phenomena.

The relation that defines the expected value $(E V)$ is:

$$
E V(\pi)=\sum_{i=1}^{n}\left(\pi_{i} p_{i}\right),
$$

where: $E V$ is expected value expressed by weighed average of various possible outputs from which each is weighed by the probability of its own occurrence, $\pi_{i}$ - effectiveness of output, $p_{i}$ - probability occurrence of output.

The relation expresses a deviation $\left(r_{i}\right)$ of each possible output from the expected value:

$$
r_{i}=\pi_{i}-E V(\pi)
$$

and is a starting point for computation of variance $\left(\sigma^{2}\right)$, that is square of deviation.

The standard deviation $(\sigma)$ is a root of variance:

$$
\sigma=\sqrt{\sum_{i=1}^{n}\left[\pi_{i}-E V(\pi)\right]^{2} p_{i}}
$$

and is used also for the measure of risk. The less is the standard deviation the smaller is the risk flown from the observed phenomenon.

The amount of the risk is understood as an absolute risk value. The relative value of risk presents a variance of feasible returns of incomes (effects) in comparison with expected liable incomes expressed in the payoff matrix. To express the relative risk the coefficient of variation is used. In the probability conception the coefficient of variation is expressed by the relation: $v=\sigma / E V(\pi)$.

The listed statistical expressions are used for the appraisal of alternatives of submitted projects and their utility, too. The standard deviation and variation coefficients are settled on the overall appraisal of economic incomes of invested sources. The risk is reviewed according to an overall utility of each single alternative and according to each single component that shares on overall income.

In the financing field an independent conception of a partial risk measurement related to a single deposit in the firm portfolio was created. This conception is termed as a conception beta $(\beta)$ and expresses a measure of systematic variability or economic return covariance of everyone part of assets from total assets. The coefficient $\beta$ is expressed by the following relation:

$$
\beta_{i I}=\frac{\sigma_{i I}}{\sigma_{I}^{2}}, \quad(i \in I),
$$

where $I$ represents the so-called market index and expresses a share of each single asset on the market of these assets. 


\section{Koncepcia štandardných rozdelení}

Koncepcia štandardných rozdelení sa spája s manažérskymi úvahami o optimistických scenároch pri posudzovaní investičných výnosov v jednotlivých projektoch. Koncepcia štandardných rozdelení spočíva $\mathrm{v}$ intuitívnych a $\mathrm{v}$ praktických prostriedkoch, ktoré použiva riadiaci pracovník pri hodnotení variantnosti možných výsledkov riešení vykonávaných na princípe očakávanej hodnoty a štandardnej odchýlky.

Vztahy medzi rizikom, štandardnou odchýlkou a koeficientom variácie vyjadruje takýto graf:

\section{Conception of standard distributions}

The conception of standard distributions used by the appraisal of the invested revenue in individual projects is connected with the managerial consideration an optimistic scenario. The conception of standard distribution consists of intuitive and practical means that a manager uses by the valuation of a possible solution executed on a principle of the expected value and standard deviation.

The relations among the risk, standard deviation and coefficient of variation are expressed in this graph:
Rozdelenie v normálnom tvare (tzv. normálne rozdelenie) má symetrické rozdelenie posudzovaných hodnôt okolo stredu očakávanej hodnoty. Ak očakávaný výstup (výnos, efekt) leží v rozpätí \pm 1 štandardnej odchýlky, tak to predstavuje cca $68 \%$ priestoru

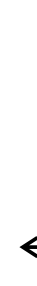

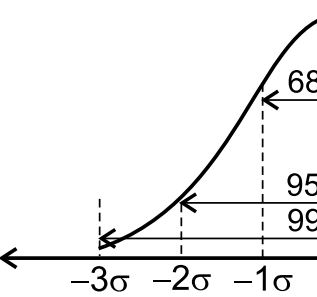
spolahlivosti odhadu výnosu. Ak sa očakávaný výnos bude pohybovat v rámci \pm 2 štandardnej odchýlky, dosiahne cca 95 \%-nú spol’ahlivost' a ak očakávaný výnos sa pohybuje $\mathrm{v}$ rozpätí \pm 3 štandardnej odchýlky, pravdepodobnost jeho výskytu je takmer 100 \%-ná.

Rozdelenie pravdepodobností možno zostavit ako sériu diskrétnych hodnôt alebo ako spojitú funkciu.

Pre všeobecné hodnotenie premennej (napr. výnosov) sa ich hodnoty najskôr štandardizujú. Štandardizovaná premenná má strednú hodnotu rovnú 0 a štandardnú odchýlku rovnú 1 . Akýkolvek výnos, náklady, zisk alebo iný pozorovaný ukazovatel' sa môže previest na štandardizovanú formu formulou:

$$
z=\frac{x-\mu}{\sigma},
$$

kde: $z$ je štandardizovaná premenná, $x$ - želatel'ný výnos a $\mu$ a $\sigma$ - stredná hodnota resp. štandardná odchýlka.

Ak napríklad želatel'ný výnos je vzdialený od strednej hodnoty o $1 \sigma$, potom $x-\mu=\sigma$, a teda $z=\sigma / \mu=1$. Ak $z=1$, hodnota želatel'ného výnosu je vzdialená o $1 \sigma$ od strednej hodnoty. Ak $z=2$, je hodnota vzdialená o $2 \sigma$ od strednej hodnoty.

Výsledky dosiahnuté touto metódou umožñujú posúdit v akom pásme sa nachádzajú očakávané alebo želatel’né hodnoty výsledkov jednotlivých častí skúmaného javu a tým posúdit i riziko s týmito hodnotami zviazané.

\section{Koncepcia teórie úžitku}

Koncepcia teórie úžitku (užitočnosti, úžitkovosti) sa zakladá na myšlienke hodnotenia rizika podla jeho využitia pre očakávaný prospech. Pri riešení špecifických úloh možno voči riziku zaujat neutrálny postoj a nebrat ho do úvahy (angl.: risk neutrality, indifference to risk), možno s ním počitat, alebo ho preferovat (angl.:
The division in a normal pattern (so-called normal distribution) has a symmetrical distribution of the regarded values around the centre of the expected value. If the expected output (income, effect) lies in the interval \pm 1 of a standard deviation then it represents approximately $68 \%$ of the area of reliability of the estimated output. If the expected output moves in the scope of \pm 2 standard deviation it reaches approximately $95 \%$ of reliability, and if the expected output moves in the scope of \pm 3 standard deviation the probability of its occurrence is almost $100 \%$ of the estimated output reliability.

The probability distribution can be formed as a set of discrete values or as a continuous function.

For the common valuation of variable (for example of incomes) their values have to be first standardised. The standardised variable has the central value equal to 0 (zero) and the standard deviation equal to 1 (one). Any income (expenses, profit or other observed indicator) can be converted to a standardised form trough the formula:

$$
z=\frac{x-\mu}{\sigma},
$$

where: $z$ is the standardised variable, $x$ - desired income and $\mu$ and $\sigma$ are the standard deviations.

If, e.g. the desired income is far away from the central value on $1 \sigma$, then $x-\mu=\sigma$, and then $z=\sigma / \mu=1$. If $z=2$, the value is off by $2 \mathrm{~s}$ from the central value.

The results achieved in using this method enable the manager to judge in which area the expected or desired values of a single result of the investigated phenomenon can be found, and thereby to judge the amount of risk connected with these values.

\section{Conception of utility theory}

A conception of utility theory in the risk valuation is based on an idea of evaluating the risk with regard to its utilisation for the expected benefit. Searching a solution for specific tasks towards the risk one can take a neutral attitude and not consider the risk at all (hence risk neutrality, indifference to risk), or one can take the 
risk seeking), alebo ho možno vylučovat, vyhýbat sa mu (angl.: risk aversion).

V praxi sa u manažérov vyskytujú všetky uvedené postoje. U niektorých podnikatel'ských činností možno viac riskovat a potom i očakávat’ riziku primeraný vyšší výnos (tzv. rizikovú prémiu). $\mathrm{V}$ iných prípadoch, najmä finančných, je rozumnejšie riziku sa vyhýbat’ a íst’ „na istotu“. A nakoniec, mnohé aktivity sa zdajú tak bezpečné, alebo peňažné poistenia proti riziku tak vysoké, že sa s rizikom ani nepočíta.

Vo všeobecnosti jestvuje snaha vyhnút sa riziku. Ak sa vyskytnú dve možné riešenia, je vel'mi pravdepodobné, že sa vyberie to riešenie, ktoré je menej rizikové. Vysvetlenie pre tento jav sa nachádza v teórii úžitku.

Podstata teórie úžitku spočíva v posudzovaní hraničného úžitku. Ak sa skúma napríklad návratnosţ vložených prostriedkov, trebárs prostredníctvom výnosov a s návratnostou viazané riziko, hraničný úžitok z d’alšieho vkladu sa posudzuje tak, že sa skúma, akú návratnost' (aký výnos) d’alší vklad prinesie. Ak je výnos z vkladu nižší ako z vkladu predchádzajúceho, je zrejmé, že je za hranicou očakávanej návratnosti. Jestvuje hranica, za ktorou je každý dalši vklad menej výnosnejší ako predchádzajúci. Hovoríme o klesajúcej miere úžitkovosti.

Vztahy medzi hraničnou úžitkovostou a rizikom vo vyššie uvedených troch prístupoch sa uvádza na obrázku. Hodnoty uvedené na $y$-ovej osi vyjadrujú tzv. jednotky užitočnosti (resp. úžitkovosti), na osi $x$-ovej hodnoty pozorovanej veličiny, napr. výnosu.

V grafe uvedená krivka $a$ vyjadruje nevšímavost’ voči riziku, krivka

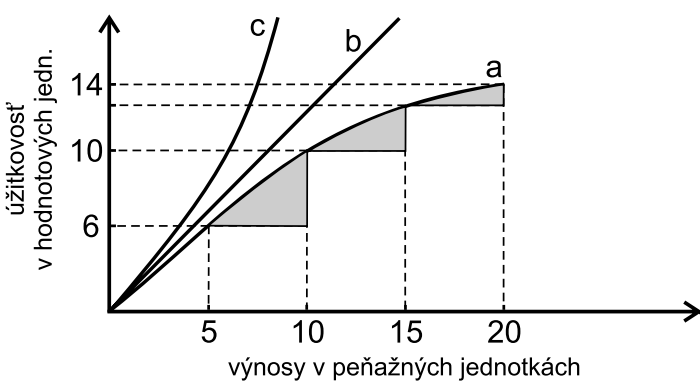
$b$ indiferentnost' voči riziku a krivka $c$ akceptovatel'nost' rizika. Označené polia predstavujú rizikový priestor pre krivku $a$ a podobne sa dá vyjadrit priestor i pre d’alšie dva priebehy kriviek. To sa, kvôli prehladnosti, v grafe neuvádza.

Z grafu sa dá usúdit, že pri postoji vylučujúcom riziko je hraničná úžitkovost̉ klesajúca. V uvedenom príklade dvojnásobok príjmu neznamená dvojnásobok úžitkovosti, ale menej. Rovnost’ medzi úžitkovostou a mierou výnosu je rovná pri neutrálnom postoji (miera rastu nie je významná ak sa aj rast zaznamená). Rast úžitkovosti sa predpokladá u tých, ktorí podnikajú s rizikom.

\section{Koncepcia vplyvu rizika na hodnotu podniku}

Koncepcia vplyvu rizika na hodnotu podniku vychádza z poznatku, že v dôsledku rastúceho rizika strácajúca sa výnosovost znehodnocuje majetok hospodárskej organizácie a ovplyvňuje tým jeho kapitálovú hodnotu. Je to celkom prirodzená úvaha, pretože klesajúca hodnota úžitku musí sa nakoniec prejaviț v hodnote podniku. Riziková analýza nemôže túto okolnost’ opomenút'. risk into account or favour it (risk seeking), or one can segregate risk, avoid it (risk aversion).

Managers in general employ all these attitudes. In business activities a manager can take more risk and then expect an adequate income to the risk (so-called danger premium). In other cases, especially financial, it seems to be rational to avoid risk and go "per certainty". And finally, many activities seem so safe, or financial insurance against risk is so high, that the risk is excluded.

Generally there is a tendency to avoid the risk. An explanation for this phenomenon can be found in the theory of utility. When there are two possible solutions, it is very feasible to choose that solution which is less dangerous. The explanation for this phenomenon can be found in the theory of utility.

The nature of utility theory consists of appraisal of marginal utility. If the payoff of inserted means and related risk is investigated, the marginal utility of further deposit is considered according to the payoff coming from this additional deposit. If the payoff coming from this deposit is lower than from the previous one it is evident that the payoff is behind the border of the expected income. There is a border behind which every next deposit pays less than the previous one. This case is known as decreasing utility measure.

Relations between the marginal utility and the risk in the aforesaid listed approach are indicated in the next picture. The values listed on $y$ axis indicate the so-called units of effectiveness (or utility), the ones on $\mathrm{x}$-axis represent the magnitudes of the observed values in currency units, for example income.

In the graph the presented curve $a$ expresses the negligence toward the risk, the curve $b$ the indifference to the risk and the curve $c$ the acceptance of the risk. The indicated dark fields represent the risk space for the curve $a$ and in the same manner a space for further two curves courses can be expressed (it is not expressed in this graph).

From the graph it can be judged that at an attitude excluding the risk the marginal utility is decreasing. In the presented example the double income does not mean double utility but a bit less utility. The equality between the utility and the measure of payoff is equal at a neutral attitude (measure of increase is not very important even in case when some increase is recorded). The increase of utility is expected at those who undertake with the risk.

\section{The conception of risk influence on firm value}

The conception of the risk influence on an enterprise value comes out from an idea that due to the risk increase the vanishing effectiveness devaluates the firm property and, thereby, affects its capital value. This is an entirely natural consideration since the decreasing value of utility must be finally signified in value of the firm. This circumstance cannot be neglected in firm's risk analysis. 
Východisková úvaha tejto koncepcie sa opiera o základný model súčasnej hodnoty $(P V)$ podniku, ktorý ma tvar:

$$
P V=\sum_{t=1}^{n} \frac{\pi_{t}}{(1+i)^{t}}
$$

Súčasná hodnota podniku $P V$ sa rovná diskontovanej hodnote jeho budúcich výnosov.

Pri podmienkach určitosti čitatel’ v danom vztahu predstavuje výnos $\pi$ a menovatel' predstavuje upravenú časovú hodnotu úrokových sadzieb pri bezrizikovej návratnosti $i$.

Pri podmienkach neurčitosti výnosy vyjadrené v čitateli hodnotou $\pi$ sa rovnajú očakávaným hodnotám výnosov v priebehu každého budúceho časového obdobia (spravidla každý rok). Očakávaná hodnota je najlepší variant možného výnosu, ktorý možno získat v každom z budúcich období.

Ked’že výnos sa nemôže stanovit úplne presne, niektoré z hodnôt sú hodnotami predvídanými, predpovedanými. Ak je podnik nútený uskutočnit výber medzi dvoma riešeniami, jedno s vyšším výnosom, ale aj s väčším rizikom, a druhé síce s nižším výnosom, ale aj s nižším rizikom, treba nájst spôsob, ako sa v danej situácii rozhodnút. To predpokladá, aby sa $v$ oboch prípadoch dala určit nielen súčasná hodnota vyplývajúca $\mathrm{z}$ budúcich výnosov, ale aby sa dala určit aj časová hodnota peňazí a časová hodnota rizika. Ako je známe, hodnota „peňazi“ je daná úrokovou mierou a hodnota rizika je daná úspešnostou (výnosovostou) daného riešenia.

Pre riešenie úlohy úpravy hodnoty podniku z hladiska rizika sa použivajú v podstate dve metódy:

- metóda činitela ekvivalentu určitosti a

- metóda upravenej hodnoty podniku.

Metóda činitela ekvivalentu určitosti vychádza z pomeru predvídanej, očakávanej absolútnej hodnoty výnosu $\mathrm{k}$ hodnote upravenej o riziko. Tento podiel sa nazýva činitel upraveného ekvivalentu hodnoty a označuje sa ako $\alpha$. Jeho tvar sa vyjadrí vztahom:

$$
\alpha=\frac{\text { očakávaná absolútna hodnota }}{\text { ekvivalentná riziková hodnota }}
$$

Ekvivalentná riziková hodnota predstavuje očakávanú absolútnu hodnotu upravenú, teda zväčšenú o riziko. S činitelom $\alpha$ sa pracuje takto: ak $\alpha<1$ - s rizikom sa nepočíta, ak $\alpha=1$ - voči riziku jestvuje indiferentný postoj, ak $\alpha>1-\mathrm{s}$ rizikom sa počíta.

Pri metóde upravenej hodnoty sa vychádza z upraveného modelu hodnoty firmy $V$, ktorý má nasledujúci tvar:

$$
V=\sum_{t=1}^{n} \frac{\alpha E\left(\pi_{t}\right)}{(1+i)^{t}}
$$

kde $V$ je očakávaný budúci výnos, $E\left(\pi_{t}\right)$ je výnos pretransformovaný na jeho ekvivalent určitosti a $\alpha E\left(\pi_{t}\right)$ je diskontovaný výnos rizikom neovplyvnenou úrokovou mierou $i$.

Tým sa získala nová súčasná hodnota podniku upravená so zretelom na rizikový činitel' $\alpha$. Uvedený výraz možno použit aj pre iné ekonomické vyhodnotenie. Napríklad pre projekty, v ktorých možno vyčíslit budúci predpokladaný výnos, alebo i pre porovnanie rizikovosti viacerých projektov.
The initial consideration in this conception is based on a basic pattern of the present value $(P V)$ of a firm and has the form:

$$
P V=\sum_{t=1}^{n} \frac{\pi_{t}}{(1+i)^{t}}
$$

The present value of enterprise $(P V)$ is equal to discount value of its future payoffs.

Under the condition of certainty the numerator in the given relation represents the income $\pi$, the denominator represents a reformatted temporal value of interest rates by the riskless return $i$.

Under the condition of uncertainty the incomes expressed in the numerator by the value $\pi$ are equal to the expected values of incomes throughout every future temporal period (generally each year). The expected value is the best variant of a possible income that can be obtained in each of future periods.

Payoffs cannot be absolutely correctly determined. Some of the values emerge as predictions, as forecasting. When a firm is forced to select between two solutions, one with a higher payoff and with a higher risk and the second with a lower payoff and with a lower risk, a manager is required to find a way how to decide in a given situation. A good solution assumes to define in both cases the present value which is implicit from future payoffs, to define the present value of currency and finally the present value of risk. The currency value is given by the rate of interest measure and the risk value is given by success (effectiveness) of the given solution.

From the viewpoint of the risk for the problem solution based on the firm value two methods are basically used:

- certainty equivalent factor and

- adjusted firm value.

The method of a certainty equivalent factor comes out from the rate of the predicted, expected absolute payoff value to the value adjusted by the risk. This rate is known as an adjusted equivalent value factor and is indicated as alfa. Its pattern is expressed by

$$
\alpha=\frac{\text { absolute payoff value }}{\text { equivalent risk value }}
$$

We work with the factor alfa in this way: if alfa $<1$ - the risk is not taken into account, if alfa $=1$ - there is an indifferent attitude towards the risk, if alfa $>1$ - risk is taken into account.

The method of an adjusted value is based on the model of adjustment of the firm value $V$, which has a subsequent pattern:

$$
V=\sum_{t=1}^{n} \frac{\alpha E\left(\pi_{t}\right)}{(1+i)^{t}},
$$

where $V$ is an expected future payoff, $E\left(\pi_{t}\right)$ is payoff transformed by its certainty equivalent and $\alpha E\left(\pi_{t}\right)$ is discounted payoff nonaffected by risky rate of interest $i$.

In this way a new present firm value adjusted with reference to the risk factor alfa was obtained. The listed expression can be used as well for other economic interpretations. For example, for evaluation of projects where future expected revenue can be calculated, or for comparison of risk among several projects, etc. 
Rizikový výnos predstavuje rozdiel medzi rizikovou a bezrizikovou očakávanou návratnostou. V takom prípade sa úroková miera $i$ nahradí inou hodnotou $k$, ktorá v sebe zahrnuje tak bezrizikovú úrokovú mieru vyjadrenú v miere návratnosti $R_{i}$, ako aj rizikový výnos vyjadrený mierou návratnosti $R_{r}$, teda:

$$
k=R_{i}+R_{r} .
$$

Základný model pre hodnotu podniku možno potom vyjadrit vo všeobecnom tvare:

$$
V=\sum_{t=1}^{n} \frac{E\left(\pi_{t}\right)}{(1+k)^{t}} .
$$

Ako príklad riešenia môžeme uviest’ graf vyjadrujúci vztah medzi trhovým a špecifickým rizikom:

Vzṫah vyjadrený obrázkom možno interpretovat tak, že súhrnné, celkové riziko, vyjadrené variáciou trhových indexov pozostáva z dvoch častí, a to z trhového, systematického rizika skúmaného druhu aktív a zo špecifického, nesystematického rizika skúmaného druhu aktív. Túto situáciu možno popísat aj vhodným druhom modelov ako sa to uvádza napríklad v literatúre uvedenej pod [3].

\section{Záver}

V príspevku sa poukázalo na niektoré z možností kvantitatívneho vyjadrenia rizika. Kvantifikáciou rizika sa vyjadruje významnost každého jednotlivého rizika, ktoré sa vyskytuje vo všetkých prípadoch, kedy je treba posúdit úžitkovost či výnosovost pozorovaných javov. Obsahovú, vecnú stránku rizika nám poskytuje príslušná vedná disciplína, ktorá sa pozorovanými javmi zaoberá. Hovorit o riziku a nepoznat jeho rozsah nie je pri skúmaní efektov z pozorovaných činností účinné.
Risk payoff presents the difference between the risk and the non-risk expected return. In this case a rate of interest $i$ is replaced by other value $k$ and includes the non-risk rate of interest expressed in rate of return $R_{i}$ as well as the risk payoff expressed by rate of return $R_{r}$,

so:

$$
k=R_{i}+R_{r}
$$

The basic model for the value of firm can be then expressed in a common pattern:

$$
V=\sum_{t=1}^{n} \frac{E\left(\pi_{t}\right)}{(1+k)^{t}}
$$

A graph expressing a relation between market and specific risks can be introduced as a solution example:

\section{Literatúra - References}

[1] BRIGHAM, E. G., HOUSTON, J. K.: Fundamentals of Financial Management, The Dryton Press, USA 1998

[2] HIRSCHEY, M., PAPPAS, J. L.: Fundamentals of Managerial Economics, The Dryden Press, USA1995

[3] MIKOLAJ, J.: Rizikový manažment, RVS FŠI ŽU, Žilina 2001

[4] ROSS, S A., WESTERFIELD, R. W., JORDAN, B. D.: Fundamentals of Corporate Finance, Irwin Inc., USA 1993 